\title{
The Intention of Indonesian High School Students to Participate in Drug Abuse Prevention Through Peer Education Activities
}

\author{
*Ira Nurmala, S.KM., MPH., Ph.D, Faculty of Public Health, Universitas Airlangga 60115 Surabaya, East Java, \\ Indonesia, iranurmala@fkm.unair.ac.id_ \\ Muthmainnah, Faculty of Public Health, Universitas Airlangga 60115 Surabaya, East Java, Indonesia \\ Riris Diana Rachmayanti, Faculty of Public Health, Universitas Airlangga 60115 Surabaya, East Java, \\ Indonesia \\ Elisa Dwi Pertiwi, Faculty of Public Health, Universitas Airlangga 60115 Surabaya, East Java, Indonesia \\ Yuli Puspita Devi, Faculty of Public Health, Universitas Airlangga 60115 Surabaya, East Java, Indonesia
}

\begin{abstract}
A cross-sectional study with a self-administered questionnaire based on the theory of planned behavior to analyze the factors associated with the intention of participating in peer education activities to prevent drug abuse among adolescents in high schools. A total of 854 students from school which held peer education activities participated in this study. This study found that $87.5 \%$ of students had the intention to participate in peer education activities. Of the eight variables which were significant in the chi-square analysis, only four were significant following the logistic regression test, namely attitude, normative belief, subjective norm, and perceived behavioral control. The students had good support from individual and social factors in drug abuse prevention activities in their school. The support of the school and related stakeholders is still needed to make an effective program of drug abuse prevention by peer- educator.
\end{abstract}

Keywords: Peer education, Participation, Intention, Students, Drug abuse prevention

Received: 20.11 .2020

Accepted: 08.12.2020

Published: 08.01.2021

\section{INTRODUCTION}

United Nations Office on Drugs and Crime (UNODC) mentioned that approximately 1 of 20 adults or a quarter billion people between 15-64 have used drugs in 2014 (UNODC, 2016). Twenty-nine million people who use drug was estimated suffer drug usage disorder, and 12 million of them were the person who injects drugs. Approximately 207 thousand mortality takes place related to drugs in 2014, along with 43.5 death per million people in 15-64 ages (UNODC, 2016).

Jawa Timur Province was the highest case province of drug abuse from 2010 to 2012. Based on the drug suspect amount, there were 6.395 suspects in 2010 and increased to 8.142 suspects in 2012 (Ministry of Health in Indonesia, 2014). According to National Narcotics Board data within 2008-2012 period, it was recorded that the highest number of drug suspect is from senior high school students (Ministry of Health in Indonesia, 2014), whereas these students were considered as the age group that has significant effect towards the nation's progress.

Students in senior high school spent seven hours a day at school commonly. The duration spent by students at school influence student's mental development (Sarwono \& Meinarno, 2009). A school environment is an imperative component that can determine someone's character. Furthermore, school is a place where students can obtain information about the importance of drug abuse prevention. The high level of knowledge helps students to understand the danger of drug abuse.

The high number of drug abuse in senior high school students can be prevented through a peer education program. This peer education program aimed to help students to overcome various problems especially drug abuse. This program was defined as activities or joint attempts than utilize its group members to entertain, accommodate, facilitate, and reconciliation (Arudo, 2008). Furthermore, peer educator was specifically trained to educate and influence their peers' behavior change. Peer education was a concept that adheres to the community approach using the method developed by members with equal position in age, status, or grade (Rahayu,2008).

The main activity of peer educator was sharing, discussing, and giving advice and support to their peers in school. The information was given by peer educator to increase students' basic knowledge, this information sharing was important as an effort to lead students toward preventive behavior. The role of peer educators was to provide information to their peers in socializing (Choukas-bradley, Giletta, Cohen, 
\& Mitchell J. Prinstein, 2015).

Ajzen behavioral theory stated three factors affect a person's intention within the behavior named attitude, subjective norm, and perceived behavioral control (Ajzen, 1991). These three factors are also determined by the background factors of the respective individual such as information or knowledge, experience, and occupation. There was a significant correlation between knowledge and behavioral intention (Guerin, Toland, Okun, \& Amy, 2018; Rohmatun \& Dewi, 2017). Another study showed that younger age more likely to participate (Sandyatma, 2012).

School drug-associated education were significant differences between male students and female students, female students have a higher intention to participate in school drug-associated education (Liao et al., 2018). Another study showed the same result where $66.4 \%$ of female respondents had a higher intention than male respondents (Firdaus, Efendi, Hadisuyatmana, Aurizki, \& Abdullah, 2019). The high intention of women may be influenced by their previous experience, as research has shown woman was often positioned on a situation that made them had no free choice from their family and society in deciding on something (Nurmala, Astutik, \& Devi, 2020). Further, this higher intention in female students led the development of a program specified only for female students that make the program non-optimal since it excluded male students (Annisa \& Nurmala, 2018). The studies showed that students' intention was an important thing to indicate their preventive behavior in drug abuse. Therefore, this study aimed to analyze the factors related to the intention of high school students to participate in peer educator activities in preventing drug abuse.

\section{METHODS}

\section{Research Design and Participants}

This study was a cross-sectional study. The participants were students in the first grade in high schools, which had a peer education program in Surabaya, Indonesia. The participants were selected using simple random sampling.

Table 1. The number of respondents from 10 senior high schools in Surabaya.

\begin{tabular}{|l|l|l|l|l|}
\hline Status of school & Coding of school & Total of Students & Number of Participants & \\
\hline State-own & A & 762 & & 85 \\
\hline & B & 653 & & 84 \\
\hline & C & 1320 & 90 \\
\hline & D & 639 & 84 \\
\hline & E & 817 & & 86 \\
\hline & F & 763 & 85 \\
\hline & G & 640 & 84 \\
\hline & H & 1216 & 89 \\
\hline Private & A & 390 & 77 \\
\hline & B & 65 & 39 \\
\hline Total & & 7265 & 803 \\
\hline Added 5\% from 803 participants to anticipate drop out & $\mathbf{8 5 4}$ \\
\hline
\end{tabular}

Table 1 shows the number of second and third-grade students from ten high schools becoming the population of the study was 7265 students. To determine the subject of the study, the researcher uses a simple random sampling technique. The minimum number of the sample needed was 803 students obtained using the Lemeshow sample calculation formula. Due to the high enthusiasm of students and to anticipate the participants who dropped out during this study, the number of the sample was increased by $5 \%$. Hence, the number of the sample in this study was 854 students. All of whom contacted was willing to be the participants, meaning that the sample has a $100 \%$ response rate.

\section{Data collection}

Data were collected using a self-administered questionnaire consisting of six direct questions in personal factors. These questionnaires also consisting the nine modifying variables which had some questions to know the categories of the variables named Behavioral belief, Outcome belief, Attitude, Normative belief, Motivation to comply, Subjective norm, Control belief, Power of control factors, and Perceived behavioral control (Table 2). 
Table 2. Amount and example of modifying variables questions.

\begin{tabular}{|c|c|c|c|}
\hline Variables & $\begin{array}{l}\text { Amount } \\
\text { questions }\end{array}$ & of & Example of questions \\
\hline \multirow[t]{2}{*}{ Behavioral belief } & 5 & & I understand about drug abuse prevention \\
\hline & & & through sharing with the peer educator \\
\hline \multirow[t]{2}{*}{ Outcome belief } & 5 & & Understanding about drug abuse prevention is a \\
\hline & & & good thing for me \\
\hline Attitude & 4 & & Sharing with peer educator give me benefits \\
\hline \multirow[t]{2}{*}{ Normative belief } & 4 & & My teacher recommended me to participate in \\
\hline & & & peer educator activities regularly \\
\hline Motivation to comply & 4 & & I care about my teacher's advise \\
\hline \multirow[t]{3}{*}{ Subjective norm } & 4 & & Most people who are important to me think that \\
\hline & & & I should participate in peer educator activities \\
\hline & & & regularly \\
\hline \multirow[t]{2}{*}{ Control belief } & 4 & & I often encounter anticipated events that place \\
\hline & & & demands my time \\
\hline \multirow[t]{4}{*}{ Power of control factors } & 4 & & If I encountered unanticipated events that place \\
\hline & & & demands on my time, it would make it more \\
\hline & & & difficult for me to participate in peer educator \\
\hline & & & activities regularly \\
\hline Perceived behavioral control & 2 & & I am likely to meet peer educator regularly \\
\hline
\end{tabular}

\section{Data analysis}

The statistical analysis was performed using IBM SPSS. All of the data were analyzed using descriptive analysis through a chi-square test and inferential analysis was conducted using binary logistic regression with a degree of significance that was less than 0.05 . The significant variables in the descriptive analysis were included in the binary logistic regression test. Also, the results of Hosmer and Lemeshow's goodnessof-fit test was $0.383(>0.05)$, which indicated a model fit to be analyzed by binary logistic regression test.

\section{RESULTS}

\section{Demographic characteristics}

854 students were involved in this study. Table 3 presents the characteristics of the respondents to the two groups of factors. The majority of the respondents had an intention to participate in peer educator activities $(83.1 \%)$. They were dominated by females $(57.5 \%), 16$ years old $(50.3 \%)$, state-own school (83.1\%), and second grade $(58.7 \%)$.

Students knew about the role of peer educator but 450 (52.7\%) students were unaware of the existence of a peer educator in school however 274 (32.1\%) students stated that they got information about health from their teachers/parents. Regarding their modifying factors of the intention for participating in peer educator activities, majority of the students had a good behavioral belief $(84.4 \%)$; outcome evaluation (83.6\%); attitude (88.2\%); normative belief (90.7\%); motivation to comply $(84.0 \%)$; control belief (84.3\%); perceived of behavioral control (87.3\%); and subjective norm (92.1\%); but not good power of control power (84.8\%).

\section{Binary logistic regression results}

Of the 15 independent variables analysed, only nine variables had significant results in the chi-square analysis, namely sex $(p=0.000)$, grade $(p=0.009)$, behavioral belief $(p=0.000)$, outcome belief $(p=0.028)$, attitude ( $p=0.000)$, normative belief $(p=0.000)$, motivation to comply ( $p=0.000)$, subjective norm ( $p=0.000)$, and perceived behavioral control $(\mathrm{p}=0.000)$.

Table 4 shows four variables had a significant effect on the intention of high school students to participate in peer educator activities by binary logistic regression test, namely attitude $(\mathrm{OR}=0.171 ; 95 \%$ CI 0.098 to 0.298 ), normative belief (OR=0.407; $95 \%$ CI 0.260 to 0.635 ),

subjective norm (OR=0.403; $95 \% \mathrm{CI} 0.256$ to 0.634$)$, and perceived behavioral control (OR=0.396; $95 \% \mathrm{CI}$ 0.236 to 0.663$)$. 
Table 3. All of the variables measured according to the participating senior high school students $(N=854)$.

\begin{tabular}{|l|l|l|l|l|}
\hline \multicolumn{1}{|l}{ Yes (\%)* } & No (\%)* & & \\
\hline & $710(83.1)$ & $144(16.9)$ & $854(100.0)$ & N/A \\
\hline Individual factors & & & & \\
\hline Age in years & & & & \\
\hline 15 & $63(87.5)$ & $9(12.5)$ & $72(8.4)$ & 0.180 \\
\hline 16 & $365(85.1)$ & $64(14.9)$ & $429(50.3)$ & \\
\hline 17 & $245(80.3)$ & $60(19.7)$ & $305(35.7)$ & \\
\hline 18 & $34(79.1)$ & $9(20.9)$ & $43(5.0)$ & \\
\hline 19 & $3(60.0)$ & $2(40.0)$ & $5(0.6)$ & \\
\hline Gender & & & & \\
\hline Male & $281(77.4)$ & $82(22.6)$ & $363(42.5)$ & $0.000^{+}$ \\
\hline Female & $429(87.4)$ & $62(12.6)$ & $491(57.5)$ & \\
\hline Grade & & & & \\
\hline Second grade & $431(86.0)$ & $70(14.0)$ & $501(58.7)$ & $0.009^{+}$ \\
\hline Third grade & $279(79.0)$ & $74(21.0)$ & $353(41.3)$ & \\
\hline Status of school & & & & \\
\hline Private & $125(86.8)$ & $19(13.2)$ & $144(16.9)$ & 0.243 \\
\hline State-own & $585(82.4)$ & $125(17.6)$ & $710(83.1)$ & \\
\hline Environmental factors & & & & \\
\hline Information Sources & & & & \\
\hline Peer & $114(83.2)$ & $23(16.8)$ & $137(16.0)$ & 0.061 \\
\hline Teacher/ parents & $220(80.3)$ & $54(19.7)$ & $274(32.1)$ & \\
\hline Training/workshop & $212(89.1)$ & $26(10.9)$ & $238(27.9)$ & \\
\hline The other & $108(80.0)$ & $27(20.0)$ & $135(15.8)$ & \\
\hline More than one choices & $56(80.0)$ & $14(20.0)$ & $70(8.2)$ & \\
\hline Awareness about the existence of peer educator in the school & & \\
\hline Aware & $343(84.9)$ & $61(15.1)$ & $404(47.3)$ & 0.225 \\
\hline Unaware & $367(81.6)$ & $83(18.4)$ & $450(52.7)$ & \\
\hline $\begin{array}{l}\text { Modifying factors } \\
\text { Behavioral Belief }\end{array}$ & & & & \\
\hline Positive & $165(65.2)$ & $88(34.8)$ & $253(29.6)$ & \\
\hline Negative & $697(84.4)$ & $129(15.6)$ & $826(96.7)$ & $0.000^{+}$ \\
\hline Outcome evaluation & $13(46.4)$ & $15(53.6)$ & $28(3.3)$ & \\
\hline Positive & $701(83.6)$ & $138(16.4)$ & $839(98.2)$ & $0.028^{+}$ \\
\hline Negative & $6(40.0)$ & $9(60.0)$ & $15(1.8)$ & \\
\hline Attitude & & & & \\
\hline Positive & $674(88.2)$ & $90(11.8)$ & $764(89.5)$ & $0.000^{+}$ \\
\hline Negative & $56(40.0)$ & $90(10.5)$ & \\
\hline Normative Belief & & & & \\
\hline Positive & & $56(9.3)$ & $601(70.4)$ & $0.000^{+}$ \\
\hline Negative & & & \\
\hline
\end{tabular}


Motivation to Comply

\begin{tabular}{|l|l|l|l|l|}
\hline Positive & $695(84.0)$ & $132(16.0)$ & $827(96.8)$ & $0.000^{+}$ \\
\hline Negative & $15(55.6)$ & $12(44.4)$ & $27(3.2)$ & \\
\hline Subjective Norm & & & & \\
\hline Positive & $479(92.1)$ & $41(7.9)$ & $520(60.9)$ & $0.000^{+}$ \\
\hline Negative & $231(69.2)$ & $103(30.8)$ & $334(39.1)$ & \\
\hline Control Belief & & & & \\
\hline Positive & $166(84.3)$ & $31(15.7)$ & $197(23.1)$ & 0.709 \\
\hline Negative & $544(82.8)$ & $113(17.2)$ & $657(76.9)$ & \\
\hline Power of Control Factors & & & & \\
\hline Positive & $162(83.5)$ & $32(16.5)$ & $194(22.7)$ & 0.963 \\
\hline Negative & $548(84.8)$ & $112(15.2)$ & $660(77.3)$ & \\
\hline Perceived Behavioral Control & & & \\
\hline Positive & $649(87.3)$ & $94(12.7)$ & $743(87.1)$ & $0.000^{+}$ \\
\hline Negative & $61(55.0)$ & $50(45.0)$ & $111(12.9)$ & \\
\hline
\end{tabular}

$*$ Percentage within sub variable.

**Percentage of the total variable.

+Included in binary logistic regression. N/A, not applicable

Table 4. Factors influencing the interest of high school students for participating in peer educator activities

\begin{tabular}{|c|c|c|c|c|c|}
\hline Variables & & OR & Lower & Upper & P-value \\
\hline \multicolumn{6}{|l|}{ Gender } \\
\hline & Male & 1 & 1 & 1 & \\
\hline & Female & 0.805 & 0.523 & 1.238 & 0.323 \\
\hline \multicolumn{6}{|l|}{ Grade } \\
\hline & Second grade & 1 & 1 & 1 & \\
\hline & Third grade & 1.257 & 0.820 & 1.926 & 0.294 \\
\hline \multicolumn{6}{|c|}{ Behavioral Belief } \\
\hline Positive & & 0.448 & 0.168 & 1.192 & 0.108 \\
\hline Negative & & 1 & 1 & 1 & \\
\hline \multicolumn{6}{|c|}{ Outcome evaluation } \\
\hline Positive & & 3.002 & 0.715 & 12.597 & 0.133 \\
\hline Negative & & 1 & 1 & 1 & \\
\hline \multicolumn{6}{|l|}{ Attitude } \\
\hline \multicolumn{2}{|l|}{ Positive } & 0.171 & 0.098 & 0.298 & $0.000^{*}$ \\
\hline Negative & & 1 & 1 & 1 & \\
\hline \multicolumn{6}{|c|}{ Normative Belief } \\
\hline Positive & & 0.407 & 0.260 & 0.635 & $0.000^{*}$ \\
\hline Negative & & 1 & 1 & 1 & \\
\hline \multicolumn{6}{|c|}{ Motivation to Comply } \\
\hline Positive & & 0.796 & 0.297 & 2.132 & 0.650 \\
\hline Negative & & 1 & 1 & 1 & \\
\hline \multicolumn{6}{|c|}{ Subjective Norm } \\
\hline Positive & & 0.403 & 0.256 & 0.634 & $0.000^{*}$ \\
\hline Negative & & 1 & 1 & 1 & \\
\hline \multicolumn{6}{|c|}{ Perceived Behavioral Control } \\
\hline Positive & & 0.396 & 0.236 & 0.663 & $0.000^{*}$ \\
\hline Negative & & 1 & 1 & 1 & \\
\hline
\end{tabular}

$* \mathrm{p}<0.01$

\section{DISCUSSION AND CONCLUSIONS}

The results of the statistical analysis of the multivariate logistic regression test revealed that the subjective norm, normative belief, attitude, and perceived behavioral control (self- efficacy) variable had a significant correlation to the intention. The Ajzen behavioral theory stated that subjective norm, attitude, and perceived 
behavioral control effect on behavior (Ajzen, 1991).

In regards to self-efficacy, the more students perceived many supportive factors and few inhibitory factors to engage in a behavior, the more they felt control over the behavior. Previous research showed that self-efficacy was significantly related to the intentions (Hapsah \& Savira, 2015; Oppong Asante, Osafo, \& Doku, 2016; Saraih et al., 2017). Individuals with high self-efficacy indicated a desire to complete their duties, had confidence in their abilities, focus on what they did and they were able to deal with risk (Indarti \& Rostiani, 2008). According to Bandura, perceived behavioral control or self-efficacy can be influenced by four sources, namely mastery experience, vicarious experience, verbal persuasion, and psychological state (Ajzen, 1991). Based on the previous research conducted in the Netherlands, social cognitive theory can influence self- efficacy significantly (Van Dinther, Dochy, \& Segers, 2011). A perceived sense of excitement, comfortable, easy access to usage, and benefit are antecedent determinants of intention (Chang, Liang, Yan, \& Tseng, 2013). Bandura's theory stated that the psychological state of an individual influence the ability to schedule meetings with peer educator regularly to solve their problem (Bandura, 1997). Parents were one of the significant others that can influence student's self- efficacy (Fan \& Williams, 2010).

Normative belief in this study was assessed from the student confidence in the approval and advice of people in the surrounding environment such as teachers, parents, friends, and peers. Teachers at Surabaya High School strongly support the existence of peer-educator activities in schools because peereducators have a great influence on their peers (Nurmala, Muthmainnah, Rachmayanti, \& Pertiwi, 2019b). Teachers had roles in peer education programs in informative support and instrumental support (Nurmala, Pertiwi, Muthmainnah, \& Rachmayanti, 2019). The role of the teacher can be enhanced by good collaboration between stakeholders in the adolescent health program (Muthmainnah et al., 2020).

Many students had a low subjective norm because of their social environment. The social environment of student peer educators had low support encouraging students to participate in peereducator programs. Research showed the students perceived the role of peer educator was greater for individuals with a more stable personality in implementing positive norms in their social environment (Usman, 2013). There were $97.7 \%$ high school students that had positive norms (meeting regularly with peer educator is important) stated they will participate in a counseling session with peer educator (Nurmala, Muthmainnah, Rachmayanti, \& Pertiwi, 2019a). A supportive attitude can be determined by the subjective norm and perceived behavior control (Ajzen, 1991; Oppong Asante et al., 2016).

The result shows many students had a positive attitude, they felt sharing and discussion with peereducators routinely would make them got many benefits. Peer educators had roles such as being friends for discussion and motivators for their peers (Nurmala, Pertiwi, Devi, Muthmainnah, \& R, 2020). Students' support for peer-educator activities can be interpreted that the majority of students had a positive attitude. A positive attitude will determine their intention to behave. Moreover, the previous study showed a stronger positive attitude will lead to a stronger intention in making decisions (Aryadhe \& Sudiksa, 2018). Other studies also stated that there was a significant relationship between attitude and behavioral intention (Ayalew \& Zeleke, 2018; Guerin et al., 2018).

This study concludes that the factors related to the intention of high school students were attitude, normative belief, subjective norm, and perceived behavioral control. Students who feel that they were able to manage their time will have a great chance of the intention to participate in a peer-education program. However, the peer educator activities should be introduced to students as early as possible starting in the first grade so they will be peer educators for their peers in the second grade. The positive attitude of participants is one of the factors that determine intention. Therefore this attitude needs to be maintained with the support of the school and related stakeholders, such as the existence of routine training for peer educators. These findings can contribute to the drug abuse prevention program and policy in Indonesia.

\section{REFERENCES}

Ajzen, I. (1991). The Theory of Planned Behavior. Organizational Behavior and Human Decision Process, $50,179-211$.

Annisa, F. N., \& Nurmala, I. (2018). Influence Perceived Benefit and Perceived Self Efficacy with Intention of Adolescent girls in Consuming Fe Tablet. Indian Journal of Public Health Research and Development, 9(4).

Arudo, T. O. O. (2008). Peer Counseling Experience Among Selected Kenyan Secondary Schools. Kenya.

Aryadhe, A. S. T., \& Sudiksa, I. B. (2018). Effects of Attitudes and Subjective Norms on Purchase Intention and Decisions. E-Jurnal Manajemen Unud, 7(3), 1452-1480.

Ayalew, M. M., \& Zeleke, S. A. (2018). Modeling the impact of entrepreneurial attitude on self-employment intention among engineering students in Ethiopia. Journal of Innovation and Entrepreneurship, 7(1), 8. 
Bandura, A. (1997). Self Efficacy -The Exercise of Control. New York: W.H. Freeman \& Company.

Chang, C.-C., Liang, C., Yan, C.-F., \& Tseng, J. S. (2013). The Impact of College Students ' Intrinsic and Extrinsic Motivation on Continuance Intention to Use English Mobile Learning Systems. Asia-Pacific Education Research, 22(2), 181-192.

Choukas-bradley, S., Giletta, M., Cohen, G. L., \& Mitchell J. Prinstein. (2015). Peer Influence, Peer Status, and Prosocial Behavior : An Experimental Investigation of Peer Socialization of Adolescents ' Intentions to Volunteer. Journal of Youth and Adolescence, 44(12), 2197-2210.

Fan, W., \& Williams, C. M. (2010). The effects of parental involvement on students' academic self-efficacy, engagement, and intrinsic motivation. Educational Psychology, 30(1), 53-74.

Firdaus, A., Efendi, F., Hadisuyatmana, S., Aurizki, G. E., \& Abdullah, K. L. (2019). Factors influencing the intention of Indonesian nursing students to work in rural areas. Family Medicine and Community Health, 7, 1-6.

Guerin, R. J., Toland, M. D., Okun, A. H., \& Amy, L. R. (2018). Using a Modi fi ed Theory of Planned Behavior to Examine Adolescents ' Workplace Safety and Health Knowledge, Perceptions, and Behavioral Intention : A Structural Equation Modeling Approach. Journal of Youth and Adolescence, 1595-1610.

Hapsah, R., \& Savira, S. I. (2015). Relationship Between Self-Efficacy and Creativity toward an Entrepreneurship Intention. Jurnal Psikologi Teori \& Terapan, 5(2), 81-90.

Indarti, N., \& Rostiani, R. (2008). Undergraduate student's entrepreneurial intention: A comparative study among Indonesia, Japan, and Norway. Journal of Indonesian Economy and Business, 23(4), 369- 384.

Liao, J., Huang, C., Lee, C. T., Hsu, H., Chang, C., Chuang, C., \& Guo, J. (2018). Risk and protective factors for adolescents ' illicit drug use : A population-based study. Health Education Journal, 77(7), 749-761.

Ministry of Health in Indonesia. (2014). Data and Health Information.

Muthmainnah, Nurmala, I., Siswantara, P., Hargono, R., Harris, N., Devi, Y. P., ... Fitriani, H. U. (2020). PowerAttitude-Interest of Stakeholders in Developing Adolescent Health Promotion Media. International Journal of Innovation, Creativity, and Change, 11(6), 287-299.

Nurmala, I., Astutik, F. N., \& Devi, Y. P. (2020). Surrounding the reason for women to continue the tradition of child marriage. Utopía y Praxis Latinoamericana, 25(2), 25-32.

Nurmala, I., Muthmainnah, Rachmayanti, R. D., \& Pertiwi, E. D. (2019a). Gender and norms related to an intention for participating in counseling sessions by peer educator. Masyarakat, Kebudayaan, Dan Politik, 32(1), 105-113.

Nurmala, I., Muthmainnah, Rachmayanti, R. D., \& Pertiwi, E. D. (2019b). What are the roles of teachers for drug abuse prevention? Opcion, 35(24), 1044-1057.

Nurmala, I., Pertiwi, E. D., Devi, Y. P., Muthmainnah, \& R, R. D. (2020). Perception of Roles as Peer Educators in High Schools to Prevent Drug Abuse among Adolescents. Indian Journal of Forensic Medicine \& Toxicology, 14(1), 1362-1366.

Nurmala, I., Pertiwi, E. D., Muthmainnah, \& Rachmayanti, R. D. (2019). Teacher's Perception of Stakeholder Support in the Peer Education Program about Drug Abuse Prevention. Indian Journal of Public Health Research and Development, 10(3), 514-518.

Oppong Asante, K., Osafo, J., \& Doku, P. N. (2016). The Role of Condom Use Self-Efficacy on Intended and Actual Condom Use Among University Students in Ghana. Journal of Community Health, 41(1), 97104.

Rahayu, D. (2008). Effectiveness of Health Promotion with Peer Educator Method on Adolescents' Knowledge and Attitudes about HIV / AIDS. Universitas Muhammadiyah Surakarta.

Rohmatun, K. I., \& Dewi, C. K. (2017). Influence of Knowledge and Religiosity to the Intention of Buying through Attitude. Journal Ecodemica, 1(1), 27-35.

Sandyatma, Y. H. (2012). Participation of Group Members in Supporting The Effectiveness Of Distribution Strengthening Activities in Bogor Regency. Kawistara, 2(3), 238-251.

Saraih, U. N., Zuraini, A., Aris, Z., Mutalib, S. A., Salha, T., Ahmad, T., \& Abdullah, S. (2017). The Influence of Self-Efficacy on Entrepreneurial Intention among Engineering Students in Malaysia. Penang.

Sarwono, S. W., \& Meinarno, E. A. (2009). Social Psychology. Jakarta: Penerbit Salemba Humanika.

UNODC. (2016). World Drug Report. Retrieved from https://www.unodc.org/wdr2016/en/drug-use.html

Usman, I. (2013). Personality, Communication, Peer Group, School Environment, and Bullying Behavior. Humanitas, 10(1), 49-60. Retrieved from https://media.neliti.com/media/publications/24533-IDkepribadian-komunikasi-kelompok-teman-sebaya-iklim-sekolah-dan-perilaku-bullying.pdf

Van Dinther, M., Dochy, F., \& Segers, M. (2011). Factors affecting students' self-efficacy in higher education. Educational Research Review, 6(2), 95-108. 